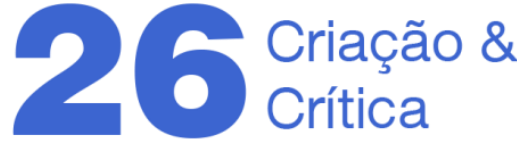

\section{A QUESTÃO DO PRIMITIVISMO E A REPRESENTAÇÃO DOS POVOS INDÍGENAS EM ANTONIO CANDIDO}

\author{
Rodrigo Octávio Cardoso ${ }^{1}$
}

\begin{abstract}
Resumo: Este artigo analisa os usos dos termos "primitivo e "primitivismo" em diversos textos de Antonio Candido, dos anos 1950 aos anos 1980, em sua relação com os povos indígenas do Brasil. Nesses textos, os termos assumem um caráter polissêmico e instável que será comentado, apresentando reflexões teóricas sobre seu significado para o pensamento do ocidente e para a compreensão da arte moderna. $\mathrm{O}$ artigo busca, dessa forma, explicitar pressupostos teóricos e ideológicos que estruturam a obra do crítico e sua concepção ampla da cultura brasileira, em sua relação histórica com os povos indígenas do Brasil.
\end{abstract}

PalaVRas-CHAVE: Antonio Candido. Primitivo. Ameríndios. Nação.

\section{THE QUESTION OF PRIMITIVISM AND THE REPRESENTATION OF INDIGENOUS PEOPLES IN ANTONIO CANDIDO}

ABSTRACT: This paper analyses the uses of the terms "primitive" and "primitivism" in several texts written by the Brazilian critic Antonio Candido from the 1950s to the 1980s, and their relation with the indigenous peoples of Brazil. In these texts, the terms assume a polysemic and unstable character, which will be commented on, presenting theoretical reflections about their meaning for Western thought and the understanding of modern art. The article seeks, in this way, to make explicit some of the ideological and theoretical assumptions that structure the critic's work and his broad conception of Brazilian culture, in its historical relationship with the indigenous peoples of Brazil.

KeYwords: Antonio Candido. Primitive. Amerindians. Nation.

"Cada vez mais, o índio é um ser humano igual a nós. Então, vamos fazer com que o índio se integre à sociedade"

- Jair Bolsonaro

"A ideia de nós, os humanos, nos descolarmos da terra, vivendo numa abstração civilizatória, é absurda. Ela suprime a diversidade, nega a pluralidade das formas de vida, de existência e de hábitos. Oferece $o$ mesmo cardápio, o mesmo figurino e, se possível, a mesma língua para todo mundo."

- Ailton Krenak

1 Doutorando em Teoria e História Literária na UNICAMP e Professor Substituto de Teoria Literária na UFRJ. rodrigooabcardoso@gmail.com 
Antonio Candido é, sem dúvida, um dos intelectuais brasileiros mais relevantes do século XX. O alcance e a qualidade crítico-analítica de seu projeto como teórico e crítico literário fizeram com que sua obra se tornasse o eixo principal de muitos currículos de literatura brasileira nas faculdades de letras em todo o país. Obras como a Formação da literatura brasileira permanecerão, ainda por muito tempo, como algumas das principais referências para a historiografia da literatura brasileira, assim como seus inúmeros ensaios sobre textos e autores, períodos e movimentos literários.

Para além de um compromisso com o campo literário e o discurso estético, a obra crítica de Antonio Candido organiza-se em torno de um projeto político de nação, pautado por um compromisso com os direitos humanos e com a justiça social. Esse compromisso se manifestou, também, através da sua atuação política e militante. O crítico foi membro fundador do Partido dos Trabalhadores, no qual permaneceu até sua morte. Foi, além disso, membro do conselho curador da Fundação Wilson Pinheiro, bem como de sua sucessora, a Fundação Perseu Abramo, responsáveis pela formação doutrinária dos membros do partido e pela formulação de suas políticas culturais (FUNDAÇÃO PERSEU ABRAMO, 2018).

Um dos textos que melhor exprime seu engajamento é "O direito à literatura", escrito em 1988. É, hoje, um ensaio familiar a quase todo estudante de letras no país. Nele, Candido afirma uma certa concepção progressiva da moral humana, observando que, em seu tempo, os discursos que defendiam abertamente a exploração das pessoas, a violência e o conservadorismo não tinham espaço na esfera pública - o que certamente não é mais válido em 2020. Mas o argumento principal do texto estrutura-se em torno da defesa da universalidade da literatura, manifestando-se através do sonho, da fabulação, dos mitos, dos cantos e narrativas populares, bem como da música erudita, da poesia e do romance de tradição europeia. Candido defende que a literatura é uma forma de "humanização", promovendo "o exercício da reflexão, a aquisição do saber, a boa disposição para com o próximo, o afinamento das emoções, a capacidade de penetrar nos problemas da vida, o senso da beleza, a percepção da complexidade do mundo e dos seres, o cultivo do humor." (2011b, p. 180). A partir dessa concepção, defende então que ela deve ser considerada um direito humano fundamental, acessível a todas as pessoas a fim de que se obtenha equilíbrio na sociedade e justiça social.

Como aponta Marcos Natali em "Além da literatura" (2006), a descrição da universalidade da literatura em "Direito à literatura", bem como o programa de Candido de defendê-la como um direito, apresentam algumas contradições quando se busca compreender a literatura na diversidade de suas manifestações. $O$ argumento de Candido, em um primeiro momento, afirma a universalidade e a necessidade fundamental da literatura para todos e para qualquer equilíbrio social. Nesse momento, Candido faz uma definição ampla e inclusiva, considerando diversas manifestações culturais distintas como literatura. No entanto, em um segundo momento, em que faz considerações sobre justiça social e literatura, sobre poder de humanização da literatura e o direito à arte, 


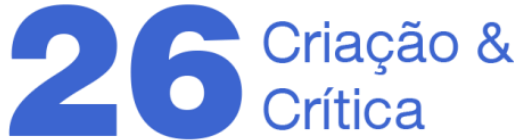

Candido menciona apenas as grandes obras canônicas da cultura de tradição europeia, ou daquelas consideradas eruditas. Termina concluindo que

O Fausto, o Dom Quixote, Os lusíadas, Machado de Assis, podem ser fruídos em todos os níveis e seriam fatores inestimáveis de afinamento pessoal, se a nossa sociedade iníqua não segregasse as camadas, impedindo a difusão de produtos culturais eruditos e confinando o povo a apenas uma parte da cultura, a chamada popular. (CANDIDO, 2011b, p. 190)

A cultura popular, em oposição à alta cultura, assemelha-se então a uma prisão, a uma condenação de inferioridade e limitação da própria humanidade. Na nossa sociedade iníqua, para o povo "ficam a literatura de massa, o folclore, a sabedoria espontânea, a canção popular, o provérbio" que são modalidades "importantes e nobres, mas é grave considera-las suficientes para as grandes maiorias" (CANDIDO, 2011b, p. 186).

Há, para Candido, portanto, uma evidente hierarquia entre as formas culturais segundo a qual a alta cultura claramente tem mais valor e mais capacidade humanizadora que a cultura popular. Há nesse argumento, além disso, um contrassenso, uma vez que a elite que detêm o acesso aos bens humanizadores - às obras eruditas oriundas da alta cultura - é também o sujeito social explorador das classes baixas. "Como é possível?" questiona então Anita Moraes a respeito de tais bens humanizadores. "Eles não estimulariam, entre outras qualidades, a boa disposição ao próximo?..." (MORAES, 2015, p. 152).

No texto, Candido hierarquiza não apenas as formas de cultura (baixa e alta), como também os sujeitos que participam delas. É o que se observa, por exemplo, na afirmação de que "fruí-la [a literatura] é um direito das pessoas de qualquer sociedade, desde o índio que canta suas proezas de caça ou evoca dançando a lua cheia, até o mais requintado erudito que procura captar com sábias redes os sentidos flutuantes de um poema hermético." (CANDIDO, 2011b, p. 180). A construção da frase parece opor justamente o baixo, o simples - exotificando a figura do índio através de estereótipos - à posição do "requintado erudito", o homem cultivado, participante de uma tradição ocidental - uma imagem ideal do próprio crítico.

A figura do indígena, como buscarei demonstrar nas próximas páginas, ocupa um lugar menor, mas bastante relevante na obra de Candido ${ }^{2}$. Sendo tema central de algumas das obras mais importantes da história da literatura brasileira, sua representação será também discutida por Candido, sempre a partir dos textos literários que analisa. De

\footnotetext{
${ }^{2}$ Este artigo concentra-se na relação que alguns textos de Antonio Candido estabelecem com os povos indígenas brasileiros. No entanto, é importante ressaltar que a obra de Candido, como se torna visível em alguns dos trechos a seguir, também estabelece uma relação tensa e complexa com a cultura e as populações negras. Em alguns textos, como "Literatura de dois gumes", o crítico denuncia o apagamento do negro e da escravidão pelo indianismo romântico, por exemplo. Entretanto, também associa, frequentemente, a cultura africana e afro-descendente à problemática noção de primitivo. Em outros textos, tais como "A passagem do dois ao três", sobre $O$ Cortiço, parece relativizar o racismo na sociedade brasileira, enfatizando como o branco português pobre vive na mesma situação que o negro no cortiço, num país de grandes desigualdades sociais. Uma análise sobre essas relações em Candido seria de muito interesse para a compreensão crítica do autor.
} 


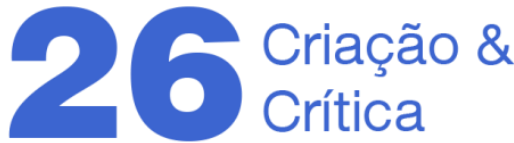

modo geral, ele está preocupado com a qualidade estética das obras, mas também em compreender de que maneira ela dialoga com a sociedade, emergindo dela e agindo sobre ela ${ }^{3}$. Não se tratando de trabalho etnográfico ou antropológico (embora o teórico tenha tido contato com tais abordagens em sua formação como sociólogo e os mencione em diversos textos, como "Estímulos à criação literária" (CANDIDO, 2011a)) não se pode esperar dele análises, descrições ou críticas mais precisas com respeito a povos indígenas concretos. Entretanto, considerando a importância central da obra de Cândido na formação dos estudos literários e para a interpretação da cultura brasileira, é preciso compreender melhor o lugar da figura do indígena em seu projeto político e em sua concepção de nação.

Apoiada em um paradigma modernista, a compreensão de Candido da figura do indígena passa pela noção de primitivo. De fato, o termo é usado por vezes como sinônimo de "índio", dos habitantes primeiros do Brasil, mas é também um termo escorregadio, abrangendo uma certa variedade de sentidos. Em Para além das palavras: representação e realidade em Antonio Candido, Anita de Moraes demonstra como, no discurso de Antonio Candido, desde sua tese de doutorado Os parceiros do rio bonito, passando pela Formação da literatura brasileira, até textos mais maduros como "Literatura de dois gumes", em que critica a colonização, além do já mencionado "Direito à literatura", forma-se um arco lógico e valorativo que vai do primitivo ao civilizado, em que se associam, ao lado do primeiro, o local, o imediato, o sentimental, o desordenado, a relação com o corporal e o material e, na outra ponta, ao lado do civilizado, o universal (muitas vezes sinônimo de europeu), o racional, a ordem e a disciplina, o espiritual e a urbanidade. Para Candido, assim, a literatura seria uma forma de passar do primeiro para o segundo, uma forma de "humanizar" ampliando a capacidade de ordenar o mundo e dominar a natureza. Dessa forma, para o crítico, escreve Moraes:

Representar o mundo (exterior - natural e social; ou interior - psicológico, o mundo dos afetos) seria ampliar o espaço do humano, da consciência humana, da cultura/civilização, sobre a natureza (a realidade concreta, que incluiria as emoções humanas). Os recursos para tanto seriam herdados dos europeus: seria o "sistema simbólico" (acervo de recursos expressivos, ou seja, de formas e temas) trazido pelos portugueses aquele capaz de representar a realidade nova (que incluiria uma sensibilidade nova, brasileira), desde que, é certo, fosse devidamente alterado (nem modificado demais, nem de menos; equilibrando o universal - o sistema simbólico herdado - e o particular - a realidade local). (MORAES, 2015, p. 3)

Em uma análise pormenorizada das formulações de Candido, Moraes explicita certos pressupostos que conduzem a trajetória crítica do autor. A estudiosa sugere que, para Candido "o escritor incorporaria ao mundo do espírito (consciência) o que antes estava refém da matéria (realidade bruta)". Dessa forma, uma certa noção de progresso

${ }^{3}$ Cf. CANDIDO, Antonio. "Crítica e sociologia" em Literatura e Sociedade; "Introdução" em Formação da literatura brasileira. 


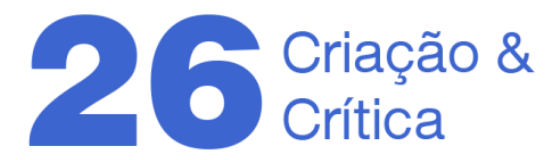

parece fundamentar a teorização de Candido, "do inconsciente ao consciente, da barbárie à civilização, da concretude à abstração, da matéria ao espírito" (MORAES, 2015, p. 75). A noção de progresso, associada em Candido à literatura, seria o fio condutor que levaria do primitivismo à civilização.

Partindo dessa análise, a fim de entender melhor o lugar destinado aos indígenas nessa construção teórica, proponho considerar o sentido dado aos termos primitivo e primitivismo por Antonio Candido em alguns textos emblemáticos de sua produção, com o objetivo de compreender sua relação com a figura do indígena, seja na história do país, seja na literatura. Buscarei também apontar algumas menções mais explícitas aos "índios", explorando a posição de Cândido em relação a eles a partir de sua crítica literária e de seu uso da noção de primitivo.

O termo "primitivo" tem um lugar importante na história do pensamento europeu, e, particularmente, no campo da estética. Em The primitive, the aesthetic and the savage (2012), Tony C. Brown analisa as transformações do sentido do conceito de primitivo no discurso filosófico europeu do lluminismo. Brown demonstra como nos ensaios de filósofos como Rousseau ou de empiristas anglófonos como Locke, Hume ou Burke o termo primitivo remete a algo fora do tempo, a algo antes da história que dá lugar à origem da história, e àquilo que é possível entender como fundamento do humano. No campo da estética, o termo diz respeito às experiências imediatas, originárias ou fundamentais. Assim, ao buscar definir os fundamentos da experiência e do humano, Rousseau fala da língua adâmica como sendo a "língua primitiva" e Burke refere-se ao gosto como uma "faculdade humana primitiva". O termo dá a entender, então, aquilo que define, de forma mais geral, o humano. O primitivo seria algo apenas distinto do nada, imediatamente fora da história, antes dela, mas tornando-a possível. Aos povos ameríndios ou aborígenes oceânicos, que não viviam segundo normas e tecnologias europeias, os europeus atribuíam o nome "selvagens". Eram, assim, definidos pela falta sem Estado e sem lei -, como uma forma dos europeus se distinguirem na categoria de civilizados, a partir do encontro colonial.

Com a emergência do historicismo, na virada do século XVIII para o XIX, todas as figuras do pensamento passam a ser comprimidas em uma história progressiva e cronológica, partindo de uma origem singular, mas concreta, no início da história, e culminando com a burguesia europeia hegemônica como telos, ou fim, dessa história. Segundo Brown, é apenas então que os termos "selvagem" e "primitivo" tornam-se intercambiáveis. Fala-se, a partir desse momento, não mais do "primitivo" abstrato como originário fundante e atemporal, mas de "primitivos", no plural, como os povos que não seguem os padrões e normas sociais europeias, que não reconhecem sua religião, seu Estado e seu sistema produtivo. Esses "primitivos" passam, então, a ser descritos como contemporâneos menos evoluídos, como imagem de uma etapa anterior da civilização, similar ao passado dos europeus, ao qual ainda estão presos.

É precisamente na confluência e na indeterminação desses dois sentidos do primitivo - o não-civilizado, selvagem, e o originário - que a imaginação modernista vai situar os povos não europeus, tornando-os matéria e fonte para seus devaneios sobre os 


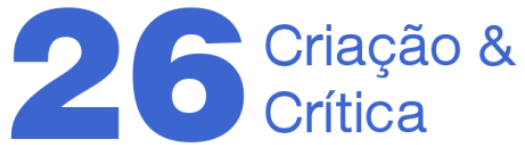

limites da representação humana (desde os padrões da burguesia eurocêntrica). Assim, os modelos antropológicos evolucionistas descobrem nos ameríndios contemporâneos uma imagem do europeu pré-histórico, e Freud vê nos aborígenes australianos um estágio inicial do desenvolvimento humano em que as neuroses dos civilizados são espelhadas nas crenças e práticas culturais do dito primitivo. O primitivismo na arte moderna, de modo particular, encontrará na figura do primitivo um lugar de experimentação para suas concepções do desejo e do sonho, da infância, da loucura e da liberdade. A respeito disso, Marianna Torgovnick escreve que "o pensamento ocidental frequentemente substitui versões do primitivo para algumas de suas obsessões mais profundas - e isso se torna uma das maiores formas através das quais o Ocidente constrói e usa o primitivo para seus próprios fins." (TORGOVNICK, 1997, p. 18)4.

Similarmente, a partir de uma robusta formação intelectual, solidamente ancorada em grandes pensadores europeus, da estética iluminista aos antropólogos e sociólogos do início do século XX. Antonio Candido articula sua visão dos indígenas a partir da noção de primitivo, reproduzindo sua polissemia característica no paradigma modernista. Assim, referindo-se à figuração do indígena na antropofagia modernista, em oposição ao romantismo, Candido escreve na Formação da literatura brasileira:

Em nossos dias, o Neo-indianismo dos modernos de 1922 (precedido por meio século de etnografia sistemática) iria acentuar aspectos autênticos da vida do índio, encarando-o, não como gentil-homem embrionário, mas como primitivo, cujo interesse residia precisamente no que trouxesse de diferente, contraditório em relação à nossa cultura europeia. O Indianismo dos românticos, porém, preocupou-se sobremaneira em equipará-lo qualitativamente ao conquistador, realçando ou inventando aspectos do seu comportamento que pudessem fazê-lo ombrear com este - no cavalheirismo, na generosidade, na poesia. (CANDIDO, 2013, p. 337, grifos meus)

Como se constrói, aqui, o significado de primitivo? No contexto mais próximo do termo, o primitivo é algo que não é o "gentil-homem embrionário", ou seja, o herói medieval mítico do romantismo europeu. Trata-se, antes, do habitante originário do território brasileiro, contemporâneo ao medieval europeu, adotado como origem telúrica na representação da nacionalidade moderna. Em contraste, a antropofagia modernista, de acordo com seus interesses, buscava nele tudo aquilo que era capaz de marcar uma distinção com relação a certa imagem da cultura brasileira - a imagem que, claramente, cultiva Candido - de que a cultura brasileira, "a nossa cultura", é europeia. O trecho sugere, ao mesmo tempo, que o indígena não era comparável ao europeu no "cavalheirismo, na generosidade, na poesia" de modo que os românticos necessitavam realçar ou inventar "aspectos do seu comportamento" para que se adequassem aos seus desígnios no papel de origem mítica. Depreende-se que, para Candido, não se pode falar

${ }^{4}$ Eu traduzo. Original: "Western thinking frequently substitutes versions of the primitive for some of its deepest obsessions - and this becomes a major way in which the West constructs and uses the primitive for its own ends." (TORGOVNICK, 1997, p. 18) 


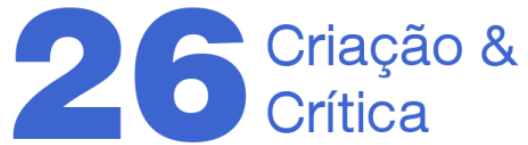

nesses traços quando se fala no indígena; que, neles, eles estariam ausentes. Um pouco mais à frente, escrevendo sobre o "I-Juca Pirama”, de Gonçalves Dias, afirma:

talvez as peças mais realizadase certamente mais belas da lira nacional sejam poemas como este último, onde nos apresenta uma rápida visão do índio integrado na tribo, nos costumes, naquele ocidentalizado sentimento de honra que, para os românticos, era a sua mais bela característica. (CANDIDO, 2013, p. 404, grifos do autor)

Aqui, novamente, o crítico fala das virtudes nobres, do "sentimento de honra", como algo "ocidentalizado". Se a palavra portuguesa "honra" evidentemente guarda relações com aspectos da cultura europeia "ocidental" entendidos como uma certa conduta virtuosa, não haveria motivos, a princípio, para pensar que a palavra não poderia ser usada para descrever costumes, valores e comportamentos entre os tupis de que fala Gonçalves Dias. Na verdade, isso é precisamente o que argumenta Lúcia Sá no capítulo dedicado ao romantismo do incontornável Literaturas da floresta:

exatamente como nos textos dos cronistas, seus poemas enfatizam a coragem e a belicosidade dos tupinambás e de seus inimigos, a qual, no entanto, tem sido atribuída pelos críticos a um mero desejo, por parte do poeta, de equiparar os indígenas brasileiros aos europeus medievais (SÁ, 2012, p. 194)

Como afirma a pesquisadora, Gonçalves Dias se baseia em inúmeras crônicas dos primeiros contatos e relatos sobre os indígenas. Além disso, o poema exibe traços "bem pouco medievais", como a disposição dos timbiras de matar o jovem tupi, mesmo ele tendo um pai cego, assim como a reação do pai, que aplaude a matança. Os valores guerreiros que se apresentam ali, como a coragem e a honra, são perfeitamente compatíveis com os padrões culturais indígenas. O que ocorre, em diversos casos, como sugere a pesquisadora no livro, é a resistência dos críticos latino-americanos em buscar fontes textuais e inspirações para textos canônicos que têm o indígena como tema nas próprias culturas indígenas, buscando-os antes, de maneira axiomática, nas tradições literárias europeias.

Alguns anos antes, em "Literatura e cultura de 1900 a 1945", redigido em 1950, Candido já esboça algumas das principais teses da Formação, de que a literatura brasileira é uma herança europeia, desenvolvida a partir de sua adaptação e aclimatação a um meio adverso. Não apenas a literatura, mas a cultura brasileira, como um todo: "Na nossa cultura há uma ambiguidade fundamental: a de sermos um povo latino, de herança cultural europeia, mas etnicamente mestiço, situado no trópico, influenciado por culturas primitivas, ameríndias e africanas." (CANDIDO, 2011a, p. 127, grifos do autor).

Aqui, Candido se coloca explicitamente na defesa da predominância quase exclusiva do fator europeu, latino, na cultura brasileira. A contribuição das culturas ameríndias e africanas, designadas como primitivas, em oposição à herança europeia, não teriam senão uma influência menor, não diretamente, mas pela via étnica. Ou seja, pode-se supor que, para o autor, não se trata de contribuições culturais relevantes, mas 


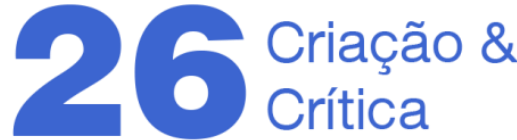

de traços primitivos, expressos em uma corporeidade latente, etnicamente, como face oculta de cultura espiritual eminentemente latina. Daí a ambiguidade: a cultura de herança, manifestação de uma espiritualidade distanciada da natureza, que a domina e a representa, como civilização superior, seria marcada por uma força contraditória: a presença de elementos étnicos primitivos, próximos da natureza, desordenados, "ameríndios e africanos". Algumas linhas depois, o argumento torna-se mais claro. 0 autor afirma que, no modernismo "O mulato e o negro são definitivamente incorporados como temas de estudo e inspiração, exemplo. O primitivismo é agora fonte de beleza e não mais empecilho à elaboração da cultura." (CANDIDO, 2011a, p. 127). Primitivismo, aqui, assume um sentido duplo. Por um lado, é a tendência da arte moderna, seguindo o movimento europeu, de incorporar temáticas, procedimentos e formas adotadas das zonas de contato colonial, de povos não eurocêntricos vivendo à margem do circuito global do capitalismo. É o caso das pinturas taitianas de Gauguin, das máscaras africanas de Picasso, da escultura surrealista de Giacometti ou da fase antropofágica de Tarsila do Amaral. Por outro lado, primitivismo era um elemento nacional brasileiro que até então havia sido "empecilho à elaboração da cultura". Ou seja, eram os elementos não europeus aqui presentes, designados acima como "ameríndios e africanos", que não apenas representavam uma contribuição menor, não espiritual, mas "étnica" à formação da cultura brasileira, mas eram um "empecilho à elaboração" dessa cultura. Seriam empecilho, depreende-se dos trechos destacados, justamente porque seriam não europeus, mas primitivos, locais, não civilizados, ao contrário da cultura brasileira, latina, de herança europeia.

Mais a frente, escreve:

Ora, no Brasil as culturas primitivas se misturam à vida quotidiana ou são reminiscências ainda vivas de um passado recente. As terríveis ousadias de um Picasso, um Brancusi, um Max Jacob, um Tristan Tzara eram, no fundo, mais coerentes com a nossa herança cultural do que com a deles. O hábito em que estávamos do fetichismo negro, dos calungas, dos exvotos, da poesia folclórica nos predispunha a aceitar e assimilar processos artísticos que na Europa representavam ruptura profunda com o meio social e as tradições espirituais. (CANDIDO, 2011a, p. 128, grifos do autor)

A avaliação de Candido sobre o desenvolvimento do primitivismo na arte moderna brasileira é a de que aqui ela segue uma tendência natural, pela presença de elementos primitivos, que ele associa com as práticas religiosas e culturais populares, o que não ocorreria na cultura europeia, onde o primitivismo seria uma "ruptura profunda". Ora, também na Europa, como reação à acelerada urbanização no final do século XIX, 0 chamado primitivismo na arte passou por um momento de volta às comunidades rurais $\mathrm{e}$ suas práticas religiosas tradicionais regionais, suas roupas e costumes, estranhos para os artistas da cidade, como nas pinturas da Bretanha de Gauguin ou nas obras da comuna de artistas de Worpswede no pós-impressionismo alemão (cf. HARRISON; FRASCINA; PERRY, 1998). Para Candido, entretanto, o primitivo parece necessariamente associado ao não europeu, fixando este último como sinônimo de civilização e universalidade. No 


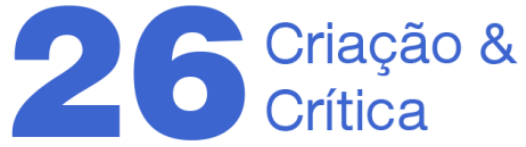

caso do primitivismo brasileiro, Candido menciona elementos da cultura popular brasileira ligados aos meios rurais, mas, também, destacadamente, ligados às culturas não brancas e ao sincretismo religioso relacionado às práticas e costumes de uma cultura mestiça aqueles que não fazem parta da "nossa cultura europeia".

Os textos dos anos 1950 de Candido são evidentemente pouco críticos ao processo violento e genocida da colonização europeia. O próprio termo colonização não aparece senão como índice de um período histórico, sem referência à violência e exploração brutal impostas no contato entre raças e culturas. A cultura e a literatura brasileiras são descritas como "transplante" da cultura europeia para os trópicos, necessitando uma aclimatação e uma adaptação ao meio e às condições locais. Alguns anos mais tarde, já no fim da década seguinte, o autor assume uma postura mais crítica e um vocabulário mais politizado com relação a esses processos históricos. Em "Literatura de dois gumes", de 1966, Candido procura delinear uma breve descrição do desenvolvimento histórico da literatura brasileira contrapondo-o ao processo colonizador, entendido como expansão violenta da civilização europeia sobre outros territórios. Escreve:

Levando a questão às últimas consequências, vê-se que no Brasil a literatura foi de tal modo expressão da cultura do colonizador, e depois do colono europeizado, herdeiro dos seus valores e candidato à sua posição de domínio, que serviu às vezes violentamente para impor tais valores, contra as solicitações a princípio poderosas das culturas primitivas que os cercavam de todos os lados. Uma literatura, pois, que do ângulo político pode ser encarada como peça eficiente do processo colonizador. (CÂNDIDO, 1987, p. 164, grifo do autor)

Aqui, como em diversos trechos citados neste artigo, Candido grifa o termo "primitivo", e outros associados, não como se quisesse distanciar-se deles, ou suspendêlos, o que se faz usualmente com as aspas, mas como se quisesse enfatizar seu uso e sua importância para o argumento. No trecho acima, a cultura brasileira hegemônica é descrita como a do "colono europeizado" que perpetua o domínio colonial do europeu sobre os povos e o território brasileiro. A própria literatura já é avaliada com um tom mais crítico, impondo "violentamente" os valores europeus sobre o território e a cultura brasileiros, "peça eficiente do processo colonizador". Entretanto, uma ambiguidade ou hesitação quanto ao valor dessa literatura e seu papel no processo colonizador se manifesta justamente ao opô-la às culturas primitivas. A construção sugere uma vitória quase heroica da literatura e da cultura do europeu na cena colonial. A literatura é descrita como uma arma eficaz "contra as solicitações a princípio poderosas das culturas primitivas que a cercavam de todos os lados". A cena lembra a de uma locomotiva atravessando um território dominado por selvagens em um faroeste hollywoodiano. Aqui, novamente, essas culturas se colocam, implicitamente, como empecilho para a elaboração da cultura e antagônicas a ela.

Essa concepção é reforçada mais algumas vezes no texto que, superficialmente, parecia crítico à colonização. Um pouco adiante, discutindo o desenvolvimento dos refinados jogos de argúcia do Barroco, Candido escreve que "isto só poderia ser 


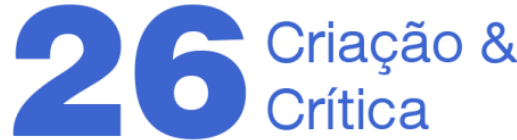

favorecido pelas condições do ambiente, formado de contrastes entre a inteligência do homem culto e o primitivismo reinante, entre a grandeza das tarefas e a pequenez dos recursos, entre a aparência e a realidade." (CANDIDO, 1987, p. 168). Aqui, o termo "primitivismo" figura como antônimo à "inteligência do homem culto". Supõe-se, assim, que as formas de vida e os habitantes nativos que não compartilhavam da cultura literária europeia, ou cuja cultura não era europeia ou herdeira da europeia seriam, dentro dessa lógica, menos inteligentes, pouco inteligentes ou, ainda, o oposto da inteligência. As "tarefas" grandiosas que o crítico menciona, fica sugerido pelo tom do texto e o cotejo com outros textos seus, eram a da promoção da cultura europeia e supressão do "primitivismo reinante" - a produção de uma literatura relevante -, mesmo dada a "pequenez dos recursos" - a falta de inteligência no ambiente primitivo. Nos mesmos termos, escreve ainda Candido:

ao estabelecer contraste com o primitivismo reinante, permitiu aos intelectuais criar um mundo de liberdade e autonomia espiritual, que preservou a existência da literatura, neutralizando o perigo de absorção pelo universo do folclore; e ao fazer do escritor um cidadão da República universal das letras, tornou-o fator de civilização do País. (CANDIDO, 1987, p. 176)

Se anteriormente o "primitivismo" se opunha à "inteligência do homem culto", aqui opõe-se a "um mundo de liberdade e autonomia espiritual". O crítico retoma sua concepção de civilização ocidental como domínio e liberdade em relação à natureza, compreendida como reino da necessidade. Dessa forma, é pelo triunfo da civilização ocidental que se adquire maior liberdade e afasta-se das condições baixas, naturais - do predomínio da matéria e do corpo - do primitivismo, que reinava até então no ambiente brasileiro. O primitivo, mais uma vez, é relegado à posição de inimigo da cultura brasileira, entrave. Para Candido, o esforço dos intelectuais neutraliza "o perigo de absorção pelo universo do folclore". O universo do folclore é associado, então, a uma forma regressão em relação ao desenvolvimento da cultura brasileira europeia e sua civilização.

Nesses textos, o termo primitivo parece deslizante, identificando-se por vezes de forma explícita com os ameríndios brasileiros, ou, ainda, com os africanos escravizados. Em outros momentos, o termo se aproxima do natural, do material, do não-cultivado, sentidos que são construídos, via de regra, pela oposição do termo à cultura europeia ou, mesmo, à cultura, de modo amplo, ou, ainda, à inteligência ou à liberdade do espírito.

A questão do primitivismo na arte moderna, particularmente, é um ponto crítico de articulação de teorias teleológicas a respeito da supremacia de uma civilização ocidental eurocêntrica sobre formas de vida outras, dadas a partir de encontros raciais coloniais. A narrativa canônica da história da arte a respeito do primitivismo postula uma diferença qualitativa abismal entre a arte moderna, que tematiza artefatos e visões de mundo consideradas primitivas, e esses artefatos, retirados de seus contextos sociais originais e denominados "arte primitiva". Um exemplo clássico dessa distinção é a exposição "Primitivism' in 20th-Century Art" realizada no Museu de Arte Moderna de Nova York em 1984. A exposição colocou lado a lado grandes obras primitivistas da arte moderna e os 


\section{$26^{\text {cinasabo o }}$}

artefatos "primitivos" que as inspiraram, trazidos da Oceania, da África e da América do Norte. Na disposição das obras e nos textos do catálogo (RUBIN, 1984), as artes primitivas são descritas como artefatos ingênuos, seus autores anônimos, suas épocas e culturas vagamente localizadas. Elas só adquirem sentido universal e valor, nesses textos, ao serem apropriadas e incorporadas pela arte moderna, descrita como transcendental e atemporal. Considerações sobre a origem dessas obras "primitivas", a técnica refinada de seus autores, frequentemente excedendo explicações de tipo funcionalista sobre seus usos, e a razão de estarem sendo expostas em museus tão distantes de sua origem, em geral passam ao largo dos debates feitos na crítica e na história da arte até o final do século $X X$.

Também Candido, ao discutir o primitivismo no modernismo brasileiro, compartilha dessas posturas, como já sugerimos acima, embora sua posição seja modulada pela consciência próxima do encontro colonial na formação da cultura brasileira. Já no final da década de 70, discutindo as obras de Mário e Oswald de Andrade, o crítico escreve:

Ele e Mário (mas não Bopp, que entrou por outro filão) exploraram com originalidade o tema básico do encontro cultural, manipulando o primitivismo de maneiras diferentes. Em Macunaíma, não apenas pela exploração do mundo primitivo, mas pela escavação do sub-solo da cultura urbana, reinterpretando-a em termos primitivos. Em Serafim, pelo tratamento do homem urbano brasileiro como uma espécie de primitivo na era técnica, que afinal se dissolve no mito. (CANDIDO, 1977, p. 85, grifos meus)

Aqui, o primitivismo é identificado, precisamente, com a técnica "ocidental" em arte, a capacidade de se apropriar de elementos pictóricos, ritmos, imagens, narrativas e formas dos povos chamados primitivos e plasmá-los em obras que dialogam com a história da arte e da literatura europeias. Mas é interessante observar as modulações que cercam a noção de primitivo no trecho. Em Macunaíma, Candido observa uma duplicidade da presença do primitivo. Opondo-o ao urbano, em primeiro lugar, fala, como sabemos, das origens de Macunaíma à beira do Uraricoera, do mundo amazônico na fronteira com a Venezuela. Aqui, a identificação dos povos amazônicos como o "mundo primitivo" se dá de forma natural, autoevidente. Em seguida, tratando do deslocamento de Macunaíma às metrópoles urbanas de São Paulo e Rio de Janeiro, Candido pondera que a presença do primitivo não está ali de forma evidente, na superfície. Mário precisa não só escavar a cultura urbana, mas reinterpretá-la em termos primitivos. Diferentemente da Europa, que, como já sugerira o crítico, precisou buscar imagens do primitivo em outro lugar (embora isso nem sempre seja verdade), no Brasil, em sua cultura urbana, o primitivo jaz enterrado sob o solo - ao mesmo tempo herança e ameaça, "perigo de absorção pelo universo do folclore".

No caso de Oswald de Andrade e seu Serafim Ponte Grande, o primitivismo se dá por uma identificação do homem urbano com o primitivo. Na verdade, como "uma espécie de primitivo na era técnica". O homem urbano, para Candido, não poderia ser identificado 


\section{$26^{\text {Criatacio } 08}$}

diretamente com o primitivo uma vez que este é definido, justamente, pela falta da técnica, pela proximidade não mediada com a natureza. Entretanto, um dos usos mais curiosos do termo aparece na página seguinte. Candido escreve:

Ambos os livros promovem uma revisão de valores mediante o choque de dois momentos culturais. Mundo primitivo e amazônico dos arquétipos, em Macunaíma, revisto na escala urbana. Mundo burguês de Serafim, atirado contra a dimensão cosmopolita da Europa, que nos orienta e fascina e, ante a qual somos primitivos." (CANDIDO, 1977, p. 85-6)

O mundo primitivo é novamente identificado com o amazônico, mas também com os "arquétipos". Modelos originários, transcendentes, que Jung localiza no inconsciente coletivo. Assim, o mundo "primitivo" não é um mundo concreto, de sociedades, vidas, sujeitos e histórias, mas um mundo de tipos transcendentes, imagens etéreas do inconsciente. Mas o mais interessante vem a seguir. Serafim Ponte Grande opõe o mundo burguês local à "dimensão cosmopolita da Europa, que nos orienta e fascina e, ante a qual somos primitivos." Embora o discurso teórico nunca se realize na forma de um sistema lógico fechado cujos termos relacionam-se por identidades e diferenças, pode ser interessante buscar equacionar a posição da cultura brasileira em relação à Europa para Antonio Candido aqui e nos textos mencionados acima. No prefácio da Formação da cultura brasileira, Candido afirma que a "nossa literatura é galho secundário da portuguesa, por sua vez arbusto de segunda ordem no jardim das Musas..." (2013, p. 11). Também fala da cultura brasileira como cultura europeia transplantada para os trópicos e, assim, da "nossa cultura europeia" (2013, p. 337). Em "Literatura e cultura de 1900 a 1945", como mencionei, fala da "ambiguidade fundamental" de "nossa cultura", "a de sermos um povo latino, de herança cultural europeia, mas etnicamente mestiço, situado no trópico, influenciado por culturas primitivas, ameríndias e africanas." (2011a, p. 127). Ora, se nossa cultura é transplantada, herdeira da cultura europeia, como ela pode ser, frente a ela, primitiva? Se é posterior, segunda, como pode ser ao mesmo tempo anterior, primeira? É verdade que o termo usado por Candido nessa posição, com o itálico, poderia ser uma referência irônica à forma como somos vistos pelos europeus. De fato, é assim que é interpretado o procedimento da antropofagia modernista de modo geral. Entretanto, se existe essa ambiguidade neste trecho específico, ela se desfaz ou, ao menos, tende para um lado no cotejo com outros textos do crítico.

A resposta parece ser que a oposição que se realiza aqui, então, não é precisamente a separação entre uma cultura urbana dita "civilizada" e um meio rural tradicional dito "primitivo". As ponderações de Candido sugerem que seríamos primitivos, antes, porque mestiços, por causa da influência étnica do ameríndio e do africano. O que se estabelece no discurso do crítico é, portanto, uma distinção racializada entre um europeu generalizado (universalizado) branco, entendido como necessariamente civilizado, apenas por ser europeu, e um brasileiro generalizado, de cultura europeia, cujos elementos étnicos decorrentes da mestiçagem constituem um perigo de regressão ao primitivo, inclusive em termos culturais - ao folclore, ou a um estado não civilizado e, 


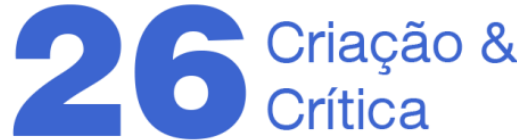

portanto, sem inteligência; a um mundo sem liberdade e autonomia espiritual, imediatamente determinado pela natureza.

O que quero enfatizar aqui não é o uso impreciso e/ou ambivalente dos termos primitivo e primitivismo nos textos de Candido. Se, por um lado, o autor nunca buscou defini-los de forma precisa, como conceitos lógico-filosóficos, por outro lado esses usos são comuns entre seus contemporâneos. Além disso, se não deixa de ser interessante observar aquilo que Alfredo Cesar de Melo chama de "tensão de um ator (o intelectual brasileiro) que se imagina pertencente a uma comunidade (a cultura ocidental), cujos principais atores (os sistemas intelectuais dos dois países centrais) o ignoram solenemente" (2016, p. 48), essa tampouco é a questão aqui.

Um relatório escrito em 1974 por "um grupo de antropólogos patriotas brasileiros que não podem revelar os seus nomes por agora, dado o regime fascista existente no Brasil", A política de genocídio contras os índios no Brasil, relata como, após 1964, uma série de denúncias contra as práticas corruptas do Serviço de Proteção ao Índio vieram a público na mídia e em veículos internacionais, gerando uma pressão internacional sobre o regime militar que levou ao fechamento do SPI e à sua substituição pela Fundação Nacional do Índio (FUNAI). Como informa o relatório, oferecendo dados e informes a respeito de fatos ocorridos em diversas regiões, apesar dos princípios fundados nos direitos humanos e dos povos originários inscritos nos regulamentos da FUNAI, as práticas genocidárias continuaram ocorrendo nos anos seguintes. Sob o pretexto de construção de estradas, ocupação de terras visando o desenvolvimento do país e a rápida integração dos povos indígenas como força de trabalho para a nação, milhares de indígenas foram mortos, grupos dissolvidos, línguas e culturas extintas.

Criado em 1910 como Serviço de Proteção ao Índio e Localização do Trabalhador Nacional (SPILTN), mesmo quando, sob o comando do Marechal Rondon (1910-1930), o SPI visava proteger a vida dos povos indígenas, o fazia com o fim último da integração. Essa mentalidade fez com que o próprio serviço fosse, muitas vezes, um agente dúbio, ajudando a propagar doenças entre os indígenas e facilitando, através de agentes corruptos, a tomada de suas terras por fazendeiros e industriais extrativistas (LIMA, 1992). Foi apenas com a ascensão dos irmãos Villas-Boas no SPI e a criação do Parque Nacional Indígena do Xingu (1961) que a política indigenista brasileira oficial passou a rejeitar o integracionismo e a adotar uma posição preservacionista, ainda que isso nem sempre ocorresse, ou ocorra, na prática. O Relatório Figueiredo, publicado em 1967 e divulgado internacionalmente, relata inúmeros abusos ocorridos contra os indígenas por latifundiários e agentes do SPI desde os anos 40 . O relatório $A$ política de genocídio contras os índios no Brasil, divulgado anonimamente como precaução contra represálias do regime militar em 1974, mostra como continuaram ocorrendo na década seguinte. Mais recentemente, a Comissão Nacional da Verdade apontou que ao menos 8.350 indígenas foram mortos pelo regime militar durante a ditadura de $1964-85^{5}$.

\footnotetext{
${ }^{5}$ http://memoriasdaditadura.org.br/cnv-e-indigenas/ (Acesso em 23/01/2020)
} 
Para compreender a pouca eficácia das políticas indigenistas no Brasil, a pouca visibilidade das violações de direitos e massacres contra os povos indígenas e como mesmo governos mais progressistas foram capazes de perpetuá-los ou serem coniventes com eles ${ }^{6}$, é preciso considerar como eles são compreendidos pelos discursos que organizam a cultura nacional e as políticas culturais e educacionais oficiais. Se os abusos contra as populações indígenas não mobilizam a opinião pública, é também porque existe uma espécie de consenso nessa cultura, ou aquilo que Raymond Williams (2015) chamaria de "estrutura de sentimentos", que entende que o índio é coisa do passado. Essa foi uma atitude generalizada no campo literário brasileiro até recentemente, exemplarmente formulada por Machado de Assis em um texto crítico clássico de 1873, "Instinto de Nacionalidade": "É certo que a civilização brasileira não está ligada ao elemento indiano, nem dele recebeu influxo algum; e isto basta para não ir buscar entre as tribos vencidas os títulos da nossa personalidade literária." ( $\mathrm{s} / \mathrm{p})$

Nos últimos anos, particularmente desde a promulgação da lei ํo 11.645 , de 2008, houve um grande salto na publicação de livros produzidos por autores indígenas e nos debates relacionados às suas culturas e relações com a cultura circundante. Obras de peso como A queda do céu (2015), de David Kopenawa, Metade cara, metade máscara (2004) de Eliane Potiguara e de inúmeros outros escritores e artistas indígenas como Daniel Munduruku, Ailton Krenak, Denilson Baniwa, Jaider Esbell e muitos outros vêm confrontando e questionando o silenciamento das vozes indígenas no campo literário brasileiro. Também nos espaços da crítica isso tem se dado em obras como o já mencionado Literaturas da Floresta, de Lúcia Sá, Contrapontos da literatura indígena no Brasil, de Graça Graúna, ou o já célebre artigo "A carta Guarani-Kaiowá e o direito a uma literatura com terra e das gentes", de Marília Librandi-Rocha. Entretanto, se quisermos que essas obras e debates sejam acolhidos e amplamente discutidos no nosso meio, é preciso repensar alguns dos pressupostos que ordenam o nosso cânone crítico.

A visão de Candido com relação aos povos indígenas, assim como a de boa parte da crítica literária do século $X X$, permanece aquela mediada pela literatura, do arcadismo e do romantismo ao modernismo. Nos textos discutidos acima, escritos entre o início dos anos 1950 e o final dos 1970, o crítico avalia, corretamente, que a figura do índio, do primitivo, servia nessas obras aos fins próprios de constituição de um discurso nacional, de acordo com as especificidades de cada período. $O$ peão inocente nas mãos dos jesuítas corruptos no Uraguai, o equivalente de um cavaleiro medieval honrado, a fim de estabelecer um ancestral análogo ao do romantismo europeu, em Gonçalves Dias e José de Alencar, e uma figura ideal de abstração e ruptura com a tradição artística europeia no

6 "Com Lula, porém, a relação se deteriorou. 'Ele começou a planejar essa ideia de levantar Belo Monte. Nós conseguimos parar a obra, só que ela recomeçou com o governo Dilma. E Dilma autorizou Belo Monte.' [...] 'Nossa luta contra Bolsonaro é a mesma que fizemos contra Lula e Dilma. Todos eles, Lula, Dilma, Bolsonaro, geraram essa divisão entre o índio e o governo. Por isso que eu venho lutando para que não haja essa divisão.'." (Raoni Metuktire em entrevista a João Fellet) https://noticias.uol.com.br/ultimas-noticias/bbc/2019/10/13/raoni-nossa-luta-contrabolsonaro-e-a-mesma-contra-lula-e-dilma.htm (Acesso em 23/01/2020) 


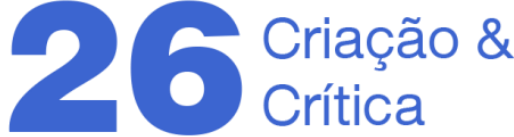

modernismo. Em cada um desses casos, Candido descreve como o índio é ficcionalizado e estilizado de acordo com certos fins ideológicos e concentra então seu interesse, como de costume, na forma e no valor estético dessa estilização, de acordo com sua concepção da tarefa do crítico literário. Mas, ao avaliar sua relação com a sociedade, o outro lado da análise literária, segundo o próprio crítico, em nenhum desses momentos relaciona 0 discurso sobre o indígena que se dá no interior do sistema literário, à sua existência concreta na sociedade brasileira. Permanece surdo e cego aos massacres e abusos sofridos pelos povos indígenas contemporâneos ao seu trabalho de crítico literário, alardeados e denunciados na mídia internacional e debatidos em meios acadêmicos bastante próximos a ele. Reinscreve assim, no circuito crítico - exterior à literatura, social - o silenciamento operado dentro da tradição literária. O índio é, novamente, representado como uma figura vazia, que não fala, não oferece modelos e reflexões sobre o mundo - ao contrário, é representado como primitivo, refratário ao suposto poder humanizador da civilização, e, assim, inclusive, menos humano até. Sua existência é tratada como oposta à inteligência, à autonomia e à liberdade espiritual, um empecilho à elaboração da cultura, um entrave para a civilização e, consequentemente, para o desenvolvimento do país. Crítico e educador, intelectual central na formação de uma ideia de cultura brasileira, Candido não apenas se omite diante do genocídio contínuo perpetrado contra os povos indígenas, mas reproduz os discursos que fornecem argumentos para aqueles que desejam justificá-lo.

A obra monumental de crítica e historiografia literária de Antonio Candido permanece uma referência incontornável para os estudos de literatura brasileira. Sua habilidade analítica, e a extensão e o fôlego de suas leituras podem ainda auxiliar gerações de críticos e estudiosos em formação. Mas aqui, como em qualquer debate acadêmico, a apresentação dos textos não pode ser feita sem as necessárias ponderações críticas sobre as limitações históricas, ideológicas e formais nas obras em questão.

\section{Referências}

ASSIS, Machado de. "Notícia da atual literatura brasileira. Instinto de Nacionalidade." Disponível em: <http://machado.mec.gov.br/obra-completa-lista/item/109-noticia-da-atualliteratura-brasileira-instinto-de-nacionalidade>. Acesso em 24 jan 2020.

ASSOCIAÇÃO DE EX-PRESOS POLÍTICOS ANTIFASCISTAS (AEPPA). A política de genocídio contra os índios do Brasil. Lisboa: AEPPA, 1974.

BROWN, Tony $\mathrm{C}$. The primitive, the aesthetic, and the savage: an enlightenment problematic. Minneapolis: University of Minnesota Press, 2012.

CANDIDO, Antonio. A educação pela noite e outros ensaios. São Paulo: Editora Atica, 1987.

CANDIDO, Antonio. Formação da literatura brasileira: momentos decisivos 1750-1880. Rio de Janeiro: Ouro sobre Azul, 2013.

CANDIDO, Antonio. Literatura e sociedade: estudos de teoria e história literária. Rio de 


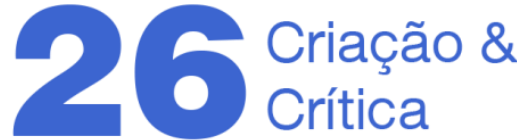

Janeiro: Ouro sobre Azul, 2011a.

CANDIDO, Antonio. Vários escritos. 2. ed. São Paulo: Livraria Duas Cidades, 1977.

CANDIDO, Antonio. Vários escritos. Rio de Janeiro: Ouro sobre Azul, 2011b.

DE MELO, Alfredo Cesar Barbosa. "Antropófagos devorados e seus desencontros: da "formação" à "inserção" da literatura brasileira". Literatura e Sociedade, São Paulo, v. 21, n. 22, p. 42-54, 2016.

FUNDAÇÃO PERSEU ABRAMO. "Antonio Candido será homenageado na sede da FPA". 18/07/2018. Disponível em https://fpabramo.org.br/2018/07/18/antonio-candido-serahomenageado-na-sede-da-fpa/. Acesso em 27/04/2020.

GRAÚNA, Graça. Contrapontos da literatura indígena contemporânea no Brasil. Belo Horizonte: Mazza Edições, 2013.

LIBRANDI-ROCHA, Marília. "A Carta Guarani Kaiowá e o direito a uma literatura com terra e das gentes". Estudos de literatura brasileira contemporânea, Brasília, n. 44, p. 165-191, 2014.

LIMA, Antônio Carlos de Souza. "O governo dos índios sob a gestão do SPI". In: CUNHA, Manuela Carneiro da. História dos Índios no Brasil. São Paulo: Companhia das Letras; Secretaria Municipal de Cultura; FAPESP, 1992. p. 155-174.

MORAES, Anita Martins Rodrigues De. Para além das palavras: representação e realidade em Antonio Candido. 1 ed. São Paulo: Editora Unesp, 2015.

NATALI, Marcos Piason. "Além da literatura". Literatura e sociedade, São Paulo, v. 11, n. 9, p. 30-43, 2006.

PERRY, Gill. "O primitivismo e o "moderno"'. In: HARRISON, CHARLES; FRASCINA, FRANCIS (Org.). Primitivismo, Cubismo, Abstração: Começo do século XX. Arte moderna: Práticas e debates. Tradução Otacílio Nunes. São Paulo: Cosac Naify, 1998.

RUBIN, William (Org.). "Primitivism" in 20th century art: affinity of the tribal and the modern. New York: Boston: Museum of Modern Art; Distributed by New York Graphic Society Books, 1984.

SÁ, Lúcia. Literaturas da floresta: textos amazônicos e cultura latino-americana. Tradução Maria Ignez França. Rio de Janeiro: EdUERJ, 2012.

TORGOVNICK, Marianna. Gone primitive: savage intellects, modern lives. Chicago: Univ. of Chicago Press, 1997.

WILLIAMS, Raymond. "Structures of Feeling". In: SHARMA, Devika; TYGSTRUP, Frederik (Org.). Structures of Feeling: affectivity and the study of culture. Concepts for the study of culture. Berlim, Munique, Boston: De Gruyter, 2015.

Recebido em: 31/01/2020

Aceito em: 03/02/2020

Referência eletrônica: CARDOSO, Rodrigo Octávio. A questão do primitivismo e a representação dos povos indígenas em Antonio Candido. Criação \& Crítica, n. 26, p., jun. 2020. Disponível em: <http://revistas.usp.br/criacaoecritica>. Acesso em: dd mmm. aaaa. 